\title{
MURALISMO MEXICANO: “MIGUEL HIDALGO ABOLIENDO LA ESCLAVITUD” DE JOSÉ CLEMENTE OROZCO
}

\author{
MEXICAN MURALISM: “MIGUEL HIDALGO ABOLISHING SLAVERY” BY JOSÉ CLEMENTE OROZCO
}

\author{
Carlos Vizconde Meneses \\ Universidad Nacional Mayor de San Marcos, Perú \\ Coz.rec@gmail.com
}

Recibido: 24-02-2021

Aprobado: 22-03-2021

\section{RESUMEN}

Carlos Vizconde Meneses es Bachiller en Comunicación Audiovisual y Medios Interactivos en la UPC, Lima. Estudiante de la maestría de Historia del Arte Peruano y Latinoamericano en la UNMSM
La época post revolucionaria en México se encuentra marcada por el ambiente político mundial y los intentos de generar una identidad nacional. Esta última fue creada con la necesidad de unificar y moldear un paradigma de temáticas en torno a México; presentando así una imagen de país con culturas ancestrales.

La ideología política del siglo XX define dos puntos de vista y paradigmas con respecto al arte. La primera es el liberalismo económico de lado de las grandes potencias occidentales; el segundo pertenece al bloque socialista comunista, protagonizado por la Unión Soviética. En México, las nuevas ideologías ampliaron las diversas perspectivas hacia el papel del arte: un enfoque utilitarista y político; contra un conceptualismo creciente, el cual dejaba de lado al objeto o la finalidad didáctica.

Bajo las características propias de su tiempo, el artista José Clemente Orozco pinta una serie de murales en las escaleras del Palacio de Gobierno de Guadalajara. En el mural central de la obra, se observa un Miguel Hidalgo efectista: un brazo arriba y una antorcha en la otra. El padre de la patria mexicana es graficado de manera particular. Es así como el artista lo rodea de distintos elementos y conceptos. Orozco presenta una interpretación personal del cura de Dolores; la cual, a su vez, responde a las ideas propias del artista hacia el escenario político y social del México post revolucionario. ¿De qué manera es presentado Miguel Hidalgo bajo la perspectiva de José Clemente Orozco? Como hipótesis, señalo que la representación del muralista no es de carácter heroico o hierático; por el contrario, Hidalgo es representado como parte del paradigma político de la post revolución.

Palabras clave: Orozco; Hidalgo; muralismo

\footnotetext{
ABSTRACT:

The post-revolutionary era in Mexico is marked by the global political environment and attempts to generate a national identity. The latter was created with the need to unify and shape a paradigm of themes around Mexico; thus presenting an image of a country with ancestral cultures.

The political ideology of the 20th century defines two points of view and paradigms concerning art. The first is economic liberalism on the side of the great Western powers; the second belongs to the socialist-communist bloc, led by the Soviet Union. In Mexico, the new ideologies broadened the diverse perspectives towards the role of art: a utilitarian and political approach; against growing conceptualism, which left aside the object or the didactic purpose.
} 
Revista Herencia, Vol. 34 (2), enero-junio, 2021.

Under the characteristics of his time, the artist José Clemente Orozco paints a series of murals on the stairs of the Government Palace of Guadalajara. In the central mural of the work, an effective Miguel Hidalgo is observed: one arm up and a torch in the other. The father of the Mexican country is depicted in a particular way. This is how the artist surrounds him with different elements and concepts. Orozco presents a personal interpretation of the priest of Dolores; which, in turn, responds to the artist's ideas towards the political and social scene of post-revolutionary Mexico. How is Miguel Hidalgo presented from the perspective of José Clemente Orozco? As a hypothesis, I point out that the representation of the muralist is not of a heroic or hieratic character; on the contrary, Hidalgo is represented as part of the political paradigm of the post-revolution.

Keywords: Orozco; Gentleman; muralism

\section{Introducción}

El presente trabajo tiene como primer objetivo describir a Miguel Hidalgo, como el héroe de la patria mexicana. Bajo esa encomienda, se parte del trabajo de Gustavo Baz (1887) autor de Miguel Hidalgo y Costilla. Ensayo histórico y biográfico; en este libro, Baz imagina a un Hidalgo revolucionario descrito desde el punto de vista de los insurgentes. Sumado a la idea del héroe, también se encuentra el lado intelectual e ideológico del personaje; razón por la cual se consulta a Jacobo Marín (2009) autor del artículo Miguel Hidalgo y la independencia y a Carlos Herrejón (1987) autor de Hidalgo: la justificación de la insurgencia. Con dichos textos se observa a un Hidalgo de distintas facetas: el religioso, el intelectual y el caudillo (o incluso "el elegido"). Fueron estas distintas visiones del personaje las cuales el artista Joaquín Ramírez plasmó en su Miguel Hidalgo de 1865. Representación del personaje que se convirtió en un modelo de fenotipo e iconografía estándar.

El artista de la Real Academia de San Carlos, no creó una imagen espontánea del religioso, sino que recogió una construcción mítica (en cierto sentido) del héroe de la insurgencia. Para el presente trabajo, es importante apuntar las diferencias del Hidalgo creado por Ramírez ante el pintado por Orozco; advirtiendo, así, que la construcción de Hidalgo responde a cualidades, gestos, objetos, vestimentas, posturas y elementos que forman parte del mito. Para esclarecer ello, se cuenta con los artículos de Guillermo Brenes (2010) el primero Miguel Hidalgo a la luz del arte: iconografía del héroe y Los rostros de Miguel 
Revista Herencia, Vol. 34 (2), enero-junio, 2021.

Hidalgo: iconografía del Héroe Nacional. Para complementar este recorrido por las interpretaciones del personaje, se encuentra José Herrera (2010) autor del artículo El rostro de Miguel Hidalgo; y Omar Gonzáles (2014) autor de La primera construcción mítica en torno a Miguel Hidalgo.

La finalidad de describir al cura de Dolores es conocerlo como un personaje con una ideología acorde con la realidad de la Nueva España; a su vez, también se pretende entender su imagen como el resultado de un proceso de construcción, con elementos y formas específicas para su representación. Por consiguiente, queda revisar el trabajo del muralista Clemente Orozco, conocer su ideología y aproximarnos a su obra en búsqueda de sus ideas sobre su contexto político y social. Partiendo de esa premisa, distintos autores intentan describir a Orozco como un animal político; el cual no está exento de la tensión creada por los bloques capitalistas y comunistas. Dicho paradigma político y contexto se pueden describir con los artículos de Héctor Jaimes (2012) y Alejandro Ortiz (2007). El primero está titulado como Filosofía del muralismo mexicano: Orozco, Rivera y Siqueiros, en el cual se describe este trío de artistas políticos y la visión particular de cada uno ante el socialismo y el indigenismo; el segundo texto, Cultura y Política en el drama mexicano post revolucionario (1920-1940), describe cómo hubo medidas estatales para promover una "identidad mexicana" y un sentimiento nostálgico hacia las culturas originarias del territorio. Con este escenario particular, podemos entrar en la mente de Orozco con los escritos José Clemente Orozco, pintura y verdad (2010) de Ricardo Castillo y Orozco ¿Pintor sin ideología? (2015) de Ana Sofía Rodríguez. Con el bagaje presentado, podremos aproximarnos a la ideología propia del artista, quien fue un crítico acérrimo, tanto de los "capitalistas" como de los "socialistas".

Una vez contemplado al artista como producto de un contexto, podemos identificar la razón del escenario presente en el Palacio de Gobierno de Guadalajara. El Hidalgo de Orozco ha sido analizado por autores como Marie Pierre Ramouche (2012) en su artículo Miguel Hidalgo, un héroe dual en sublevación de José Clemente Orozco. La autora hace un señalamiento importante al encontrar un paralelismo entre el insurgente y Prometeo, ser mítico al cual Orozco presenta en otras de sus obras. Dicho esto, el trabajo mencionado 
Revista Herencia, Vol. 34 (2), enero-junio, 2021.

se centra en describir sólo al personaje mas no los elementos ni los extremos del personaje principal; espacio donde se describen personajes y elementos que aluden al escenario político local y global. Razón por la cual, veo pertinente complementar el trabajo de Marie Pierre, rescatando sus aportes y sumando más elementos al análisis del mural de Clemente Orozco.

\section{Miguel Hidalgo, el criollo}

La imagen de Don Miguel Hidalgo y Costilla Villaseñor fue creada con el fin de legitimar la lucha insurgente, la cual dio en consecuencia la creación de la nación mexicana. Así como nos menciona Gustavo Baz (1887) en "Miguel Hidalgo y Costilla: ensayo histórico biográfico", la situación de la Nueva España era controlada por los ibéricos, quienes a su vez manejaron y acapararon distintas actividades sociales y administrativas. Baz describe un escenario de atraso social, ejercido por un gobierno central muy alejado de la Nueva España; donde, a pesar de los discursos de evangelización, los naturales eran empleados como servidumbre "sin otro horizonte ni otro porvenir". De igual manera, se presenta una brecha ideológica con Europa. En México, aún se repetían los discursos religiosos y creacionistas; por otro lado, la vanguardia filosófica europea se mantuvo al margen, en favor de esta espiritualidad conservadora. El autor hace un claro énfasis en las distintas deficiencias del gobierno y la administración del reino de la Nueva España; ello sirve para presentar a quienes apunta como los iniciadores de la insurgencia: el sector criollo. Debido al hermetismo de los ibéricos, se imposibilitó el acceso de los criollos a trabajos de administración pública. Dicha imposibilidad fue acompañada por una serie de medidas que marcaban una clara ventaja entre los nacidos en Europa y América. Como menciona Baz, el peninsular poseía toda ventaja por sobre cualquier habitante de las indias; estos tenían la posibilidad de adquirir empleos por encargo del rey, además de la posibilidad de "especular con la justicia". De igual manera, el autor menciona que el clero poseía similares condiciones favorables. Es así como el grupo de los criollos, al no poseer iguales 
Revista Herencia, Vol. 34 (2), enero-junio, 2021.

derechos que sus padres españoles, comienzan a propiciar el escenario para la expulsión de la influencia ibérica en Nueva España (p. 5-9).

Así como describe Baz (1887), la clase criolla era letrada y ocupaba los espacios académicos y sociales. El autor describe este grupo enfatizando su carácter bohemio, pero a la vez intelectual. Sus participantes resultaron ser jóvenes quienes dedicaron el capital familiar a placeres y educación (p. 9). Los estudios de Miguel Hidalgo son un capítulo fundamental para describir su ideología y postura política. Siendo él hijo de un administrador de hacienda (p. 10), tuvo acceso a una educación privilegiada, la cual le dio acceso al mundo académico y político. Como relata Jacobo Marín (2009), el padre de Hidalgo decidió por una educación a cargo de la Compañía de Jesús, por lo cual el niño cursó estudios en el Colegio de Francisco Javier. A raíz de la expulsión de la orden jesuita de los Reinos de España y el cierre de la institución, Hidalgo sigue sus estudios en el Colegio de San Nicolás. Realiza estudios en gramática latina, teología, retórica y la "nueva filosofía que impartían en los colegios jesuitas" (ello referente al "populismo", tema descrito más adelante). Es así como obtiene un bachiller en letras, además de obtener uno en artes por parte de la Pontificia Universidad de México. Para 1774 recibe el diaconado y ejerce como profesor de filosofía; cuatro años después, es consagrado como sacerdote. Debido a sus estudios, el padre de la patria manejaba distintas lenguas, las necesarias para abrir su panorama ideológico y social. Hidalgo manejó el francés y el latín; mientras que su acercamiento con los naturales de su hacienda, le dio la habilidad de manejar las lenguas locales: otomí, náhuatl y purépecha (p. 27).

\section{El populismo jesuita}

Es preciso atender a la formación de Miguel Hidalgo dentro de las instituciones educativas. Ello se debe a los planteamientos ideológicos propios de la orden jesuita: el populismo, corriente ideológica que da forma al paradigma político que gestó la lucha insurgente. Dentro del texto "Hidalgo: la justificación de la insurgencia", Carlos Herrejón (1983) 
Revista Herencia, Vol. 34 (2), enero-junio, 2021.

menciona que dicha corriente ideológica parte de los postulados del jesuita español Francisco Suárez en su libro Defensa de la Fe Católica. Las autoridades londinenses de 1613 calificaron la obra como "un demoledor ataque, no solo al anglicanismo, sino también al pretendido derecho divino de los reyes". De ese modo, la postura jesuita se presenta al gobernante como el receptor del poder de su pueblo. Este no se proyecta a partir de un personaje, sino en "la comunidad, en todo el pueblo, en toda la nación" (p. 32). El "populismo jesuita" postula la democracia como un método de gobierno; a su vez, no niega los defectos de este sistema. Los postulados de Suárez presentan el concepto de "pacto social", el cual puede romperse en caso de tiranía.

Se entiende por tiranía la degradación del gobierno legítimo, en cuando que el gobernante "todo lo ordena hacia su medro personal, desatendiendo el bien común o aflige injustamente a sus súbditos, robando, matando, pervirtiendo o perpetrando contra la justicia otras semejantes cosas de manera pública y frecuente (Herrejón, 1983, p. 33).

El concepto de tiranía es importante debido a que de ello depende el pacto social. Para el populismo jesuita, ante la imposibilidad de rehabilitar al gobernante, se debía tomar medidas extremas como la expulsión o la muerte del monarca (p. 33). Así como nos explica Herrejón, el populismo tuvo dos vertientes, y su diferencia consiste en el modelo de gobierno realista. El primer grupo se encuentra a favor de la imagen de un rey, razón por la cual se presentan distintos postulados que describen el cómo continuar las líneas de herencia para los cargos de poder. Ante aquel tipo de selección, el segundo grupo profesó la eliminación total de la imagen del monarca; imposibilitando así cualquier influencia de este para dejar a cargo a un gobierno gestionado por el pueblo. Como sigue relatando el autor, fueron estos postulados los que propiciaron la expulsión de la orden de los jesuitas de los Reinos de España en 1767; ello con la finalidad de evitar que la Compañía de Jesús expanda sus "opiniones sanguinarias", las cuales provocaron "reyes insultados" y pueblos amotinados (p. 35-6). Herrejón identifica la influencia de los textos de pensamiento populista y "anti tiranía”. Ambos postulados son estudiados por Miguel Hidalgo desde sus días de magisterio (p.39). Una vez descubiertos los criollos, la lucha insurgente nace con 
Revista Herencia, Vol. 34 (2), enero-junio, 2021.

una postura anti tiránica, cuestión que se grafica en los diversos calificativos negativos hacia los españoles; los cuales, a los ojos de los criollos de Nueva España, eran un reino externo al suyo, déspota y tiránico, quienes "han calificado a los americanos de indignos de toda distinción y honor" (p. 41-2).

Al atender las dos vertientes del populismo, es de interés conocer la postura de Miguel Hidalgo. Gustavo Baz (1887) recopila un texto del caudillo, el cual puede esclarecer sus intenciones y finalidad de su lucha insurgente. Entendiendo así, que no deseaba una sucesión de monarcas; sino que, por el contrario, deseaba una propia determinación de los pueblos mediante el sistema de representación republicano:

Si nosotros no peleamos contra nosotros mismos, la guerra está concluida y nuestros derechos á salvo. Unámonos, pues, todos los que hemos nacido en oste dichoso suelo, veamos desde hoy como extranjeros y enemigos do nuestras prerrogativas á todos los quo no son americanos. Establezcamos un Congreso quo se ponga de representantes de todas las ciudades, villas y lugares de este reino, que teniendo [de] objeto principal mantener nuestra santa religión, dicte leyes suaves, benéficas y acomodadas á las circunstancias de cada pueblo: ellos entonces gobernarán con la dulzura de padres, nos tratarán como á sus hermanos, desterrarán la pobreza moderando la devoción del reino y la extracción de su dinero, fomentarán las artes, se avivará la industria, haremos uso libro do las riquísimas producciones de nuestros feraces países, y á la vuelta de pocos años, disfrutarán sus habitantes de todas las delicias quo el Soberano Autor de la naturaleza ha derramado sobre este vasto continente (Hidalgo en Baz, 1887, p. 138-9).

Además del texto que presenta conceptos como la organización y determinación de los pueblos, se puede también rescatar la posición de Hidalgo con respecto al monarca español Fernando VII. Ello se puede observar en el documento Copia y Plan del Gobierno Americano (1810) dentro del libro Los Sentimientos de la Nación de José María Morelos (2013). En este texto escrito por Miguel Hidalgo, podemos observar que el primer punto por tratar es el modelo de gobierno. Es así como el caudillo plantea un congreso conformado en totalidad por criollos; a pesar de las tendencias anti ibéricas, en el texto especifica que dicho organismo debe sostener "los derechos del señor don Fernando VII" (p.50), razón por la cual podemos entender su postura acerca de la libre determinación de 
Revista Herencia, Vol. 34 (2), enero-junio, 2021.

los pueblos de la Nueva España; pero a su vez, no pertenecía a la rama radical del populismo jesuita. Ello se demuestra en las menciones que hace Hidalgo con respecto al rey de España Felipe VII.

\section{La imagen de Hidalgo}

Es necesario entender que el nombre de Miguel Hidalgo fue fundamental para la lucha insurgente, ello debido al enfrentamiento de imágenes entre insurgentes y realistas. Atendiendo a esto, podemos observar un dato importante: el cura de Dolores no fue retratado en vida. Si bien su nombre e ideas siguieron hasta el fin de la lucha insurgente, no existe registro de su apariencia. Muy aparte de las distintas descripciones hacia su persona. Es así que luego de su muerte en 1811, Miguel Hidalgo sigue presente en distintos escritos e interpretaciones de su fenotipo. El proceso de creación de la imagen del caudillo se puede describir en el artículo de Guillermo Brenes Tencio (2010) titulado "Miguel Hidalgo a la luz del arte: iconografía del héroe nacional - padre de la patria mexicana (siglos XIX y XX)". El autor describe que la imagen del personaje es una construcción mítica, y debido a la importancia de este, fue encargo del Estado Nacional mexicano el descubrir (o mostrar) un "verdadero" rostro del héroe. En así que dicha labor cayó en manos del Primer Congreso Constituyente de México, el cual se encargó de legislar en favor de exaltar la figura del cura de Dolores. Posteriormente, el breve mandato de Maximiliano de Habsburgo intentó adoptar la imagen de Hidalgo encargando una representación de carácter sereno y paternalista. Por otra parte, los protagonistas de la Guerra de Reforma también adoptaron a Hidalgo, dotando al personaje con un "generalísimo", "profeta republicano" y "teórico revolucionario". Así como menciona Brenes, el papel de héroe insurgente fue adoptado durante la Guerra de Reforma, la cual fue considerada como una segunda independencia mexicana (p. 56). A pesar de la prohibición de las imágenes de Hidalgo después de su prematura muerte, su presencia se mantuvo viva gracias a los distintos relatos, poesías y arengas de los insurgentes, todas 
Revista Herencia, Vol. 34 (2), enero-junio, 2021.

con la finalidad de describir su accionar, así como conservar sus características físicas (p.58). A pesar de esto, podemos encontrar distintas interpretaciones de la apariencia de Miguel Hidalgo, las cuales, a su vez, presentan distintas facetas de éste: la del religioso, intelectual y la del caudillo. Esta última se encuentra presente en representaciones como la de Claudio Linati (figura 1) y Luis Montes de Oca; ambos grafican a un Hidalgo con traje militar, espada y pistola. La primera muestra a un caudillo en una cruzada religiosa, lo cual demuestra al levantar una cruz y observar a los cielos. Por el otro lado, la segunda ilustración muestra al religioso como un militar francés, el cual sujeta una lanza (p. 59-60).

Figura 1. Miguel Hidalgo de Claudio Linati

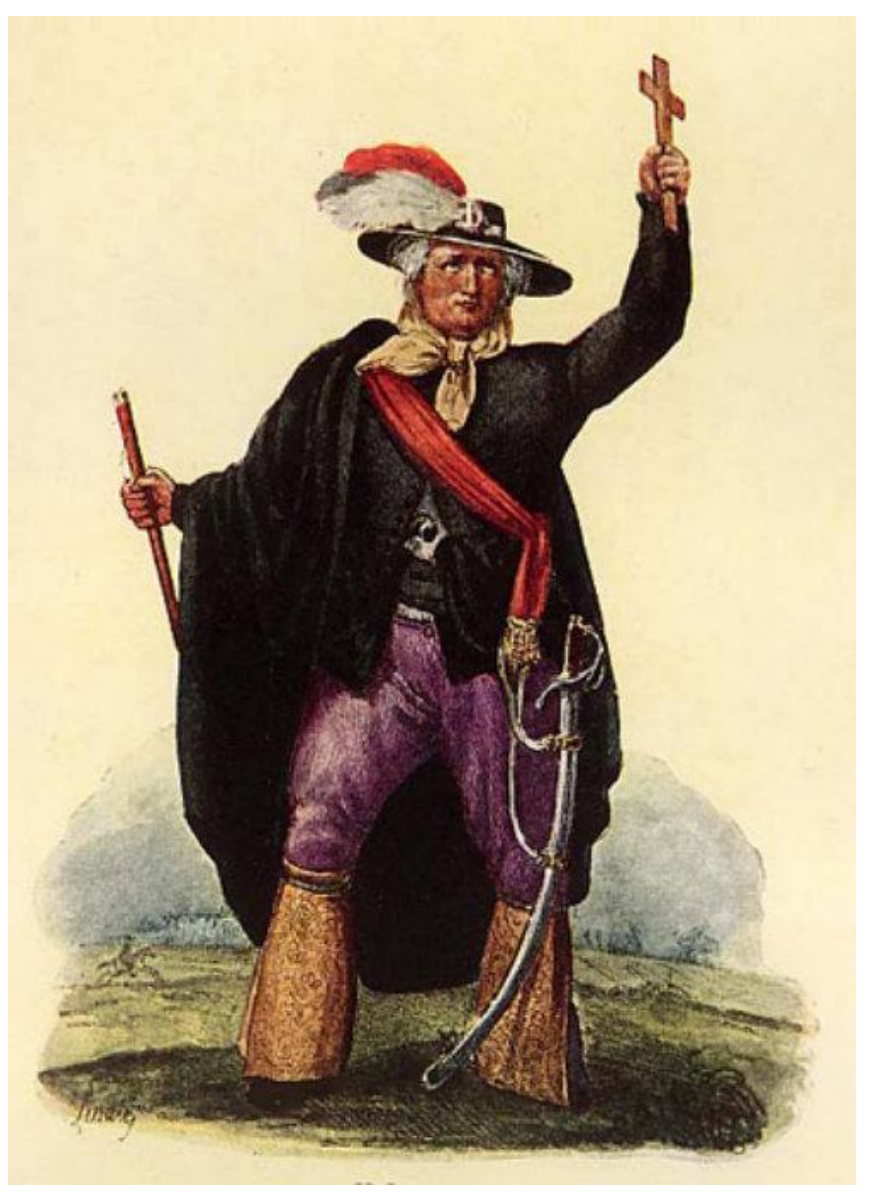

Fuente: Trajes civiles, militares y religiosos de México (1828) 
Revista Herencia, Vol. 34 (2), enero-junio, 2021.

A pesar de la clara perspectiva militar, las representaciones de Miguel Hidalgo son más próximas a las de un religioso e intelectual. Brenes ejemplifica esta faceta con las representaciones hechas por Clemente Terrazas, Antonio Serrano, Juan Nepomuceno Herrera y Joaquín Ramírez (figura 2). En dichas representaciones se pueden encontrar similitudes como la tonalidad de la piel. El cura de Dolores era representado con piel cobriza y con nariz aguileña; posiblemente con la finalidad de rescatar los rasgos físicos de los criollos. De igual manera, las imágenes muestran un personaje con una levita negra; además de representarlo calvo y con pocos cabellos canosos a los lados de la cabeza. En el caso de los cuadros de Joaquín Ramírez y Antonio Serrano, podemos observar elementos externos que suman información al personaje. En ambos se grafica un Miguel Hidalgo de pie frente a una mesa y un librero. Además de estos significantes de intelectualidad, hace presencia a la Virgen de Guadalupe. Como señala Brenes, la falta de cabello no sólo corresponde a un indicador de edad, sino que también enfatiza la "brillantez" (inteligencia o astucia) de una persona (p. 61-2). Del mismo modo, la Virgen de Guadalupe hace presencia por ser el estandarte de la lucha insurgente. Como nos indica Gonzáles (2014), es esta imagen símbolo del mestizaje cultural y religioso, por lo cual el sector criollo adoptó el culto guadalupano como una forma de reafirmación local y de rechazo ante cualquier vestigio de hispanidad (p.172). 
Revista Herencia, Vol. 34 (2), enero-junio, 2021.

Figura 2: Miguel Hidalgo por Joaquín Ramírez (1865)

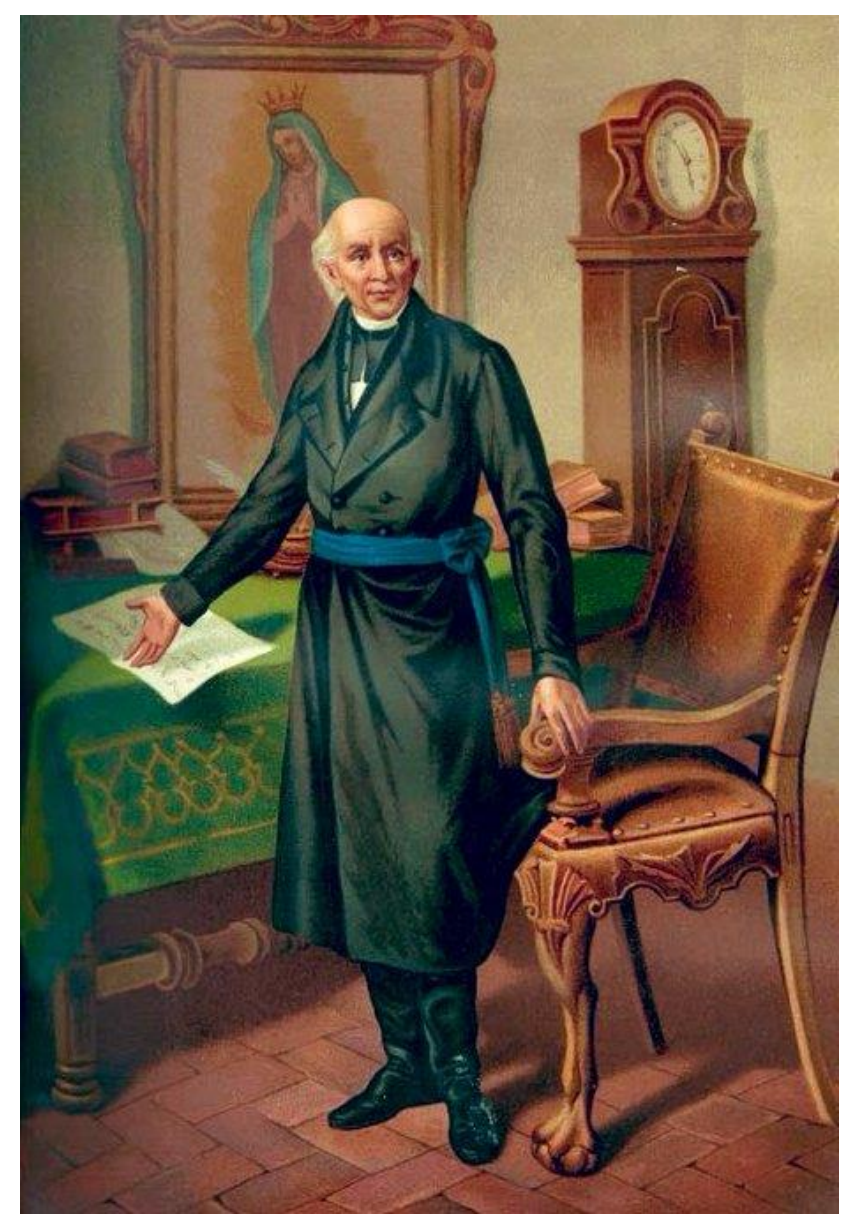

Fuente: Galería de los Insurgentes, Palacio Nacional, México D.F.

\section{El Hidalgo de Rivera y Siqueiros}

La imagen Miguel Hidalgo también fue interpretada por los otros dos miembros de la "triada de muralistas mexicanos". La interpretación más próxima a la creación de Joaquín Ramírez es el Hidalgo de Diego Rivera en su mural "Epopeya del pueblo mexicano" (figura 3). La obra ubicada en la escalera principal del Palacio Nacional de México, presenta la historia nacional bajo la perspectiva del artista. Entre los variados personajes, Miguel Hidalgo es representado junto a los conspiradores de la insurgencia. El cura de Dolores se encuentra calvo y vestido con levita; sumado a ello, se puede encontrar a la Virgen de 
Revista Herencia, Vol. 34 (2), enero-junio, 2021.

Guadalupe tras el caudillo. El rostro presenta una expresión confiada. Sólo se puede observar el cuello y hombros del héroe nacional. A pesar de ello, al contemplar la composición total de mural, Hidalgo se encuentra "en el medio" de la historia mexicana de Rivera. El busto del religioso se ve también enfatizado por las distintas miradas y elementos alrededor de este. Es importante mencionar la presencia de soldados de la Revolución Mexicana mirando en dirección a Hidalgo. Podría afirmarse que, si bien el mural intenta relatar la historia de México en general, este repara en enfatizar la figura de Hidalgo, al colocarlo incluso por encima del símbolo nacional de México: el águila y la serpiente.

Figura 3: "Epopeya del pueblo mexicano" de Diego Rivera (1954)

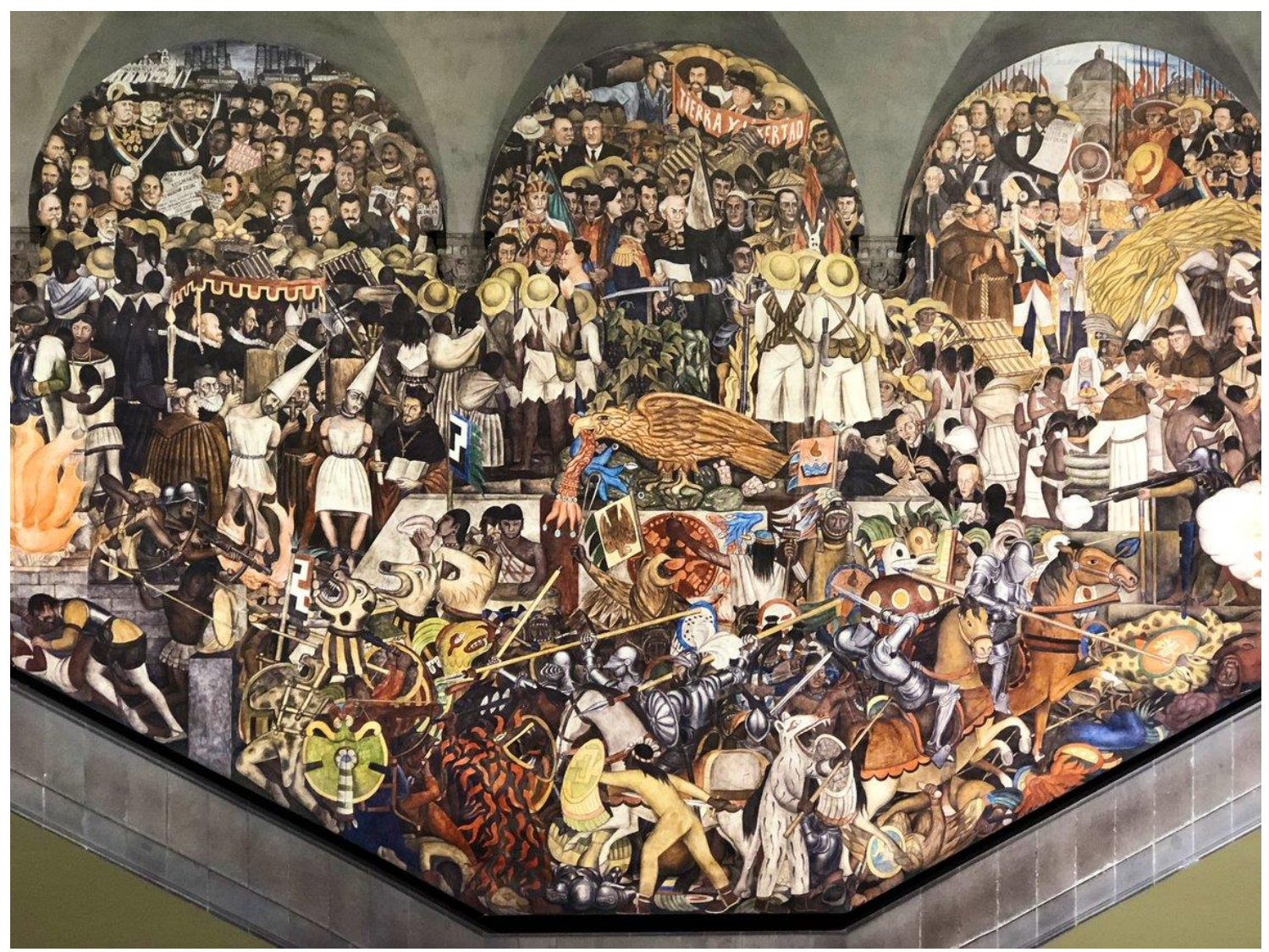

Fuente: Palacio Nacional, México D.F. 
Revista Herencia, Vol. 34 (2), enero-junio, 2021.

De igual manera, podemos entender que la perspectiva de Siqueiros también responde al énfasis del personaje. Ello se puede denotar en la obra "Excomunión y fusilamiento de Hidalgo" (figura 4), la cual presenta a un funcionario religioso con una lanza de oro. La punta de la lanza se encuentra en el piso y atraviesa un gorro frigio (representación de la Revolución Francesa). La presencia de la lanza con una cruz marca la clara posición de la iglesia en contra de las ideas de Hidalgo. Como relata el título, Hidalgo acaba de ser acribillado; se observan los orificios de balas en la pared y en la mano derecha del caudillo. A pesar de la escena, Hidalgo se mantiene en pie, con postura firme y una mirada que mira directamente al espectador. Claramente, el sentido poético de la escena denota el manejo del discurso para Siqueiros. Tanto Rivera como Siqueiros presentaron a Miguel Hidalgo y Costilla como un individuo importante para la historia de México, además de imaginarlo bajo la faceta de religioso e intelectual. 
Revista Herencia, Vol. 34 (2), enero-junio, 2021.

Figura 4: "Excomunión y fusilamiento de Hidalgo" de David Siqueiros (1953)

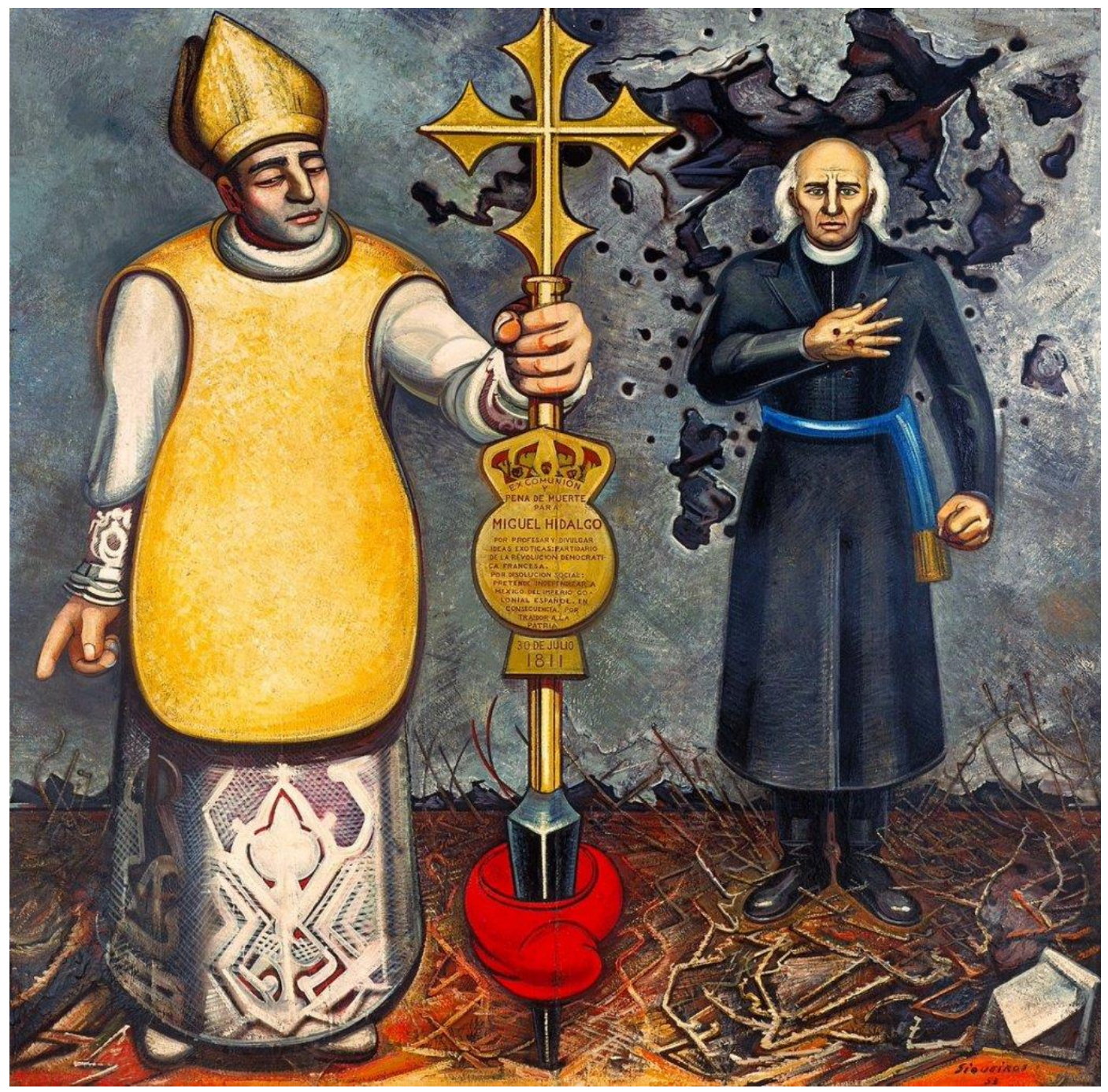

Fuente: Tesorería de la Universidad Michoacana de San Nicolás de Hidalgo, Michoacán, México 
Revista Herencia, Vol. 34 (2), enero-junio, 2021.

\section{El arte mural del México post revolucionario y la postura de Clemente Orozco}

Como relata José Clemente Orozco (1945) en su auto biografía, nace en 1883 en Ciudad Guzmán. Realiza estudios en la Escuela Primaria Anexa a la Nacional de Maestros, ubicada en la calle Licenciado Verdad. En la misma calle se ubicaba la imprenta de Venegas Arroyo y el taller de José Guadalupe Posada. Durante la lectura, se puede entender la trascendencia de este encuentro. Orozco va a crear afición hacia el dibujo y a la colección de las impresiones de Posada. A pesar de su acercamiento con el arte, a partir de 1897 pasa un periodo de tres años en la Escuela de Agricultura de San Jacinto, donde realiza estudios para mantener el negocio de su familia. Posteriormente, regresó a la Academia de San Carlos, donde realizó trabajos como dibujante de arquitecto o caricaturista en El Imparcial (p. 8-9).

Como se ha mencionado, José Clemente Orozco es agrupado dentro de la "triada del muralismo mexicano". La razón de esta relación es descrita por Pablo Neruda en el catálogo de la Exposición de Pintura Mexicana en el Museo Nacional de Bellas Artes de Santiago de Chile (1973). El poeta hace énfasis en la necesidad de graficar la historia de su nación. Reflexiona sobre los tres como personas comprometidas con su pueblo, el cual, a su vez, posee "trágica grandeza, épica serenata, cadencia del corazón más volcánico de nuestro continente" (p. 6). Si bien encontramos discursos que pretenden abogar por una "identidad latinoamericana", se puede entender que los tres artistas fueron agrupados debido a su labor en temas históricos y sociales de su país, forjando así una identidad mexicana con base en las representaciones en las artes. Con respecto a ello, la obra de Héctor Jaimes (2012) titulada Filosofía del muralismo mexicano: Orozco, Rivera y Siqueiros, posee una descripción del contexto necesaria para entender las necesidades de la nación mexicana post revolucionaria. Como señala Cockcroft, en Jaimes la Revolución Mexicana fue un enfrentamiento entre distintos bandos sin un norte claro en común. Aparecen agrupaciones como el Partido Liberal Mexicano con intenciones de una revolución

violenta y de corte anti capitalista; por otro lado, se tenía la premisa de que dicho movimiento tenía que ser encabezado por obreros y campesinos. Retomando a Jaimes, 
Revista Herencia, Vol. 34 (2), enero-junio, 2021.

estos pensamientos liberales se logran afianzar en la Constitución de 1917. Como menciona el autor, no se debe dejar de lado el impacto de las ideas filosóficas de Karl Marx y sus repercusiones en México. Es así como Jaimes realiza un paralelismo entre las ideas de Marx y los resultados de la Revolución Mexicana. En palabras del autor, el marxismo apunta a "la eliminación de las clases sociales, suprimir la propiedad privada de los medios de producción, y superar la explotación y el trabajo enajenado"; a pesar de ello, Jaimes es claro en calificar dicho gobierno como una "revolución incompleta" (p.23). Igual perspectiva posee José Clemente Orozco (1945), el cual calificó la Revolución Mexicana como "pura confusión e inconsciencia; lo demás fue lo mismo y quedó todo igual que antes" (p. 20).

Como relata el mismo Orozco, no tuvo participación dentro del conflicto de la Revolución Mexicana. Menciona que hubo intentos por relacionar la falta de su mano izquierda a un enfrentamiento bélico. Sin embargo, el mismo artista desmiente aquella relación. Clemente Orozco perdió su mano izquierda al jugar con pólvora en una temprana edad. Además de ello, el muralista describe una Revolución Mexicana hundida en el desorden y en el libertinaje. Señala la existencia de distintos bares y casinos, cada uno repleto de feligreses, los cuales podrían ser proletarios o burgueses. Dentro de estos espacios, la policía realizó distintas batidas con la finalidad de reclutar jóvenes para el ejército de Huerta. A pesar de los intentos de la policía, Orozco nunca fue levantado debido al estado de su mano izquierda (p. 24-5). La auto biografía del muralista describe una revolución lejos de una romanización o de aires heroicos.

\footnotetext{
Otra guerra sin cuartel, otra lucha por el poder y la riqueza. Subdivisión al infinito de las facciones, deseos incontenibles de venganza. Intrigas subterráneas entre los amigos de hoy, enemigos mañana, dispuestos a exterminarse mutuamente llegada la hora (José Clemente Orozco, 1945, p. 29).
}

El arte creado durante el México post revolucionario puede atender a dos vertientes que explica Octavio Paz en Rodríguez (2015). El escritor propone las definiciones de arte comprometido y arte como emoción. El primero refiere a un arte que desea lograr un 
Revista Herencia, Vol. 34 (2), enero-junio, 2021.

efecto en las masas. En el escenario mexicano, se buscó la reacción de estos a favor de un discurso oficialista y a favor de las ideas promovidas por la Unión Soviética. Por otro lado, se encuentra el arte como emoción. Paz apunta a que tanto Rivera como Siqueiros realizaron aquel arte comprometido. Eran artistas que habían tenido contacto con aquella vanguardia de pensamiento marxista o presencia durante el conflicto de la revolución, razón que los separa de la producción de Clemente Orozco. Para el poeta, este artista se encontraba en el otro extremo: la realización del arte como emoción. Ello es justificado al afirmar que la obra de Orozco generaba emociones y mostraba una ideología propia de su persona (p. 169). Esto se puede entender al conocer que el trabajo de Orozco no era solventado por el estado mexicano. Además, se debe tener en cuenta la libertad que tuvo al realizar trabajos como los de la Escuela de Investigaciones Sociales en Nueva York. Dicho mural no estaría exento a controversias debido a la presencia de Lenin, entonces líder de la Unión Soviética (Orozco, 1945, p. 66). De igual manera, la autora Marie Pierre Ramouche (2012), en el artículo “Miguel Hidalgo: héroe dual en sublevación de José Clemente Orozco" hace mención de la clara diferencia entre Orozco y los otros dos muralistas. Ello es explicado en la falta de interés hacia la romanización del pasado o de "ocuparse" de las cuestiones indígenas con el arte. Además de ello, se señala que su obra no es una extensión de las "glorias nacionales"; por lo cual, la producción de Orozco no es usada como propaganda política (p. 50)

No pretende penetrar la realidad a través o "con el arma" de la ideología, sino que "arremete contra ella" y sus encarnaciones (Paz en Rodríguez, 2015, p. 169). 
Revista Herencia, Vol. 34 (2), enero-junio, 2021.

\section{El arte para José Clemente Orozco, la resistencia academicista}

En el artículo “De Héroes y Máquinas” de Rita Eder (1983), se recoge la definición de Clemente Orozco sobre el arte:

\footnotetext{
"desesperada ambición de dominar la realidad a partir de la lucha de las formas cerradas y abiertas, mecánicas y humanas, silenciosas y demandantes, austeras y caóticas" (p.155).
}

La frase que destaca la autora pretende demostrar la importancia de las cuestiones compositivas (academicistas) para Orozco. Dentro de su auto biografía, podemos encontrar anotaciones sobre la academia y sobre las nuevas tendencias que trajeron las vanguardias a las instituciones de enseñanza en arte. Orozco (1945) menciona la presencia del artista Fabrés en La Academia de San Carlos, quien implementó un método de enseñanza de dibujo de carácter demandante. Se realizaba el dibujo de un modelo para, después del largo proceso, compararlo con una fotografía. Como menciona Orozco: "aprendían a dibujar, a dibujar de veras, sin lugar a dudas" (p. 11). Posteriormente, aquel método academicista fue repudiado por las nuevas generaciones que abogaban por un pensamiento "vanguardista" para la educación. Ello desembocó en un cambio en los métodos de enseñanza artística lo cual, para el artista con estudios, generó más de un punto de discusión. A pesar de la entonces calidad de enseñanza, el muralista también denuncia la dependencia hacia el extranjero. Existió un prejuicio sobre la enseñanza fuera de México, por lo cual todo artista proveniente del extranjero era "consagrado". A pesar de este rechazo a las tendencias extranjeras, el artista menciona que es necesario aprender tanto de los "maestros antiguos" como de los extranjeros. No piensa en su país como incapaz de producir productos artísticos o referentes propios. Es creyente de la posibilidad y potencial humano de México. “iPero nosotros podríamos también producir un Kant o un Hugo!" (p. 15). A pesar del deseo de una producción intelectual propia, Orozco tiene ciertos desencuentros con cuestiones como la democratización de la pintura. Ello sucede durante los primeros años del muralismo mexicano, a partir de 1922. Orozco 
Revista Herencia, Vol. 34 (2), enero-junio, 2021.

califica como "infantil" la idea de abrir la posibilidad de producción a cualquier individuo. Así menciona la presencia de distintos personajes con labores ajenas al dibujo, los cuales no poseían preparación alguna. El artista denuncia que, debido a esta visión, las cuestiones academicistas habían sido dejadas de lado. Se daba demasiada libertad creativa a individuos sin formación artística, incluso se caía en sinsentidos como la nula corrección del profesor hacia los trabajos. Esto, porque dicha idea no sólo promovía la incorporación de gente "del pueblo", sino que además justificaba la poca instrucción aludiendo que lo académico podía arruinar el "candor e inocencia" del arte de este sector social. Orozco hace énfasis en escenarios ridículos en los cuales al analfabeto se lo presenta como un agente que va a producir un material más "natural", propio de "su alma", sin contaminación o prejuicios. Como respuesta al sinsentido, Clemente Orozco presenta una fábula que relaciona aquel sinsentido dentro de los grandes espacios del arte. Se relata la historia de un burro al cual se le colocó un pincel en la cola y se le acercó un lienzo. El cuadro resultante fue expuesto en Europa donde los críticos de arte obtuvieron distintos conceptos e ideas sobre el cuadro del burro, sin dejar de lado los elogios hacia la obra de este animal (p. 38-9).

\section{El arte comprometido}

Como menciona Héctor Jaimes (2012) en "Filosofía del muralismo mexicano: Orozco, Rivera y Siqueiros", los principales lineamientos de las nuevas propuestas artísticas hacen presencia en el Manifiesto del Sindicato de Obreros, Técnicos, Pintores y Escultores. En dicho documento, Siqueiros afirma una clara postura para dejar la pintura de caballete debido a que esta representa una manifestación "burguesa" o de la aristocracia; razón por la cual, apunta a producir obras monumentales y a la vista de todos aquellos que conforman "el pueblo". A sus palabras: "belleza para todos, de educación y de combate". Otro punto importante en el manifiesto son las apreciaciones hacia el indígena. La perspectiva racista de la época proveyó la idea de una "raza originaria" a la cual los artistas 
Revista Herencia, Vol. 34 (2), enero-junio, 2021.

mexicanos debían recurrir para describir "lo mexicano". Es así como el manifiesto presenta un claro lineamiento con las ideas de Marx y Engels, así como señala Jaimes (p. 36).

Por su parte, Orozco (1945) presenta una férrea crítica hacia estos planteamientos como la eliminación del lienzo y la romanización de la cuestión indígena. Con respecto al caballete, el artista apunta hacia lo ilógico de la propuesta. Ello llevaría al rechazo de todo arte pasado sobre dicho soporte. Además, imposibilitaría que este "arte movible" terminase en casa de los propios proletarios. La cuestión del denominado "arte proletario" fue criticado por Orozco de una manera tajante. Es descrita una clara contradicción con respecto al consumo de este arte. Es así como Orozco menciona que las clases altas son las que terminan consumiendo aquel arte para proletarios, llenando así sus casas con muebles y cuadros con dicha temática. Por otro lado, el obrero no se encontraba en posibilidad de adquirir aquellos elementos que lo romantizan; razón por la cual, sólo las clases altas puede adquirir las piezas. Otro punto que menciona Orozco es que el tema no lucía atractivo para los mismos proletarios. Estos personajes se encontraban agotados de sus labores y horarios, por lo cual aquellas representaciones podrían no causar el efecto deseado. En contraposición al deseo por crear una identidad, el muralista menciona que esa clase obrera se encuentra en un proceso de alienación. Los proletarios están apegados a costumbres y modismos norteamericanos, mientras que los "burgueses" son quienes consumen aquel arte supuestamente destinado a las clases trabajadoras (p. 43-4).

Del mismo modo, el manifiesto de aquel arte comprometido intenta rescatar el legado de una "raza originaria"; apelando así, a una reinterpretación y renacimiento del denominado arte precortesiano. Como es de esperarse, Orozco también ataca estos planteamientos románticos sobre el indígena y su participación dentro del lenguaje del arte post revolucionado. En primer lugar, el muralista menciona que aquellas representaciones de los indígenas eran producidas y comercializadas al margen de estos, por lo que muchos no tuvieron siquiera conocimiento sobre la temática. El destino de las obras eran los hogares de Estados Unidos, llenos de personas distintas a aquella "raza" indígena protagonista del material. De igual manera, Orozco pone en duda aquella "función revolucionaria" que profesa el manifiesto del sindicato. Se plantea entonces la pregunta: “¿Cuándo [una obra 
Revista Herencia, Vol. 34 (2), enero-junio, 2021.

de arte] es realmente subversiva?". Dicha temática, apunta el artista, no causa más que la limitación creativa en los artistas. Se presenta un escenario donde es "la colectividad la que tiene que imponer al artista su gusto y sus preferencias". Consecuentemente, se presenta la siguiente pregunta: “¿quiénes son los representantes de la colectividad y cómo podrían interpretar finalmente el gusto de los representados? (p. 46-7). De igual manera, Octavio Paz, en Rodríguez (2015), hace mención sobre la delimitación de las temáticas artísticas. El poeta menciona que aquel "arte comprometido" era de carácter moralista, de ideas rígidas e inauténticas, parámetros promovidos por una premisa gubernamental, la cual limita las posibilidades creativas. La visión de Paz funciona en favor de mostrar a Orozco como un artista fuera de aquel paradigma del estado mexicano. Rodríguez hace mención a Paz debido a las distintas observaciones que este tiene sobre Orozco. Se presenta al artista como un personaje que duda de las corrientes ideológicas de su época. Se menciona que no fue dogmático. A pesar de haber participado en el Partido Comunista Mexicano, no llegó al mismo grado de instrucción que Rivera y Siqueiros. Es así como, para Octavio Paz, Orozco va a representar un aire neutral dentro del ferviente caldo ideológico del México post revolucionario (p. 168-9).

\section{La ideología de Orozco}

Como se ha descrito, Orozco se encuentra sumergido en un ambiente ideológico y en un proceso de cambio del paradigma artístico. Aun así, el artista presenta una postura claramente crítica hacia diversos temas. No cae en los dogmatismos de los otros miembros de la triada de muralistas. Esta ideología particular es explicada por Rita Eder (1983), la cual apunta la relación que tiene Orozco con el "Círculo Délfico", un grupo de estudio el cual conoce en su segundo viaje a Estados Unidos. Los planteamientos de la agrupación es el rescate del humanismo en el occidente, la crítica a la máquina ${ }^{1}$, y a la sociedad de masas. Dentro del grupo se manejaron lecturas clásicas de filósofos como Nietzsche y Spengler.

\footnotetext{
${ }^{1}$ La metáfora de "La máquina" hace referencia al sistema industrial y de consumo masivo del siglo XX.
} 
Revista Herencia, Vol. 34 (2), enero-junio, 2021.

Otro punto importante sobre los lineamientos ideológicos de este grupo es el planteamiento del arte como un "mecanismo de salvación" (p. 149), quizá en función de una premisa utilitarista o a favor de la transformación de las masas. Este último concepto es importante debido a que, como menciona Eder, las denominadas masas serían un conjunto de personas que pierden su individualidad y pueden representar inestabilidad social para los teóricos de derecha (p. 159).

Clemente Orozco difiere ideológicamente de Rivera y Siqueiros; a pesar de estar agrupados como una "triada", estos dos últimos tuvieron una postura dogmática y romántica. José Clemente Orozco es un artista crítico. No se comprometió en un conflicto abierto, pero sí logra ver las contradicciones durante estos "carnavales". Aquella visión particular va a plasmarse en su estilo personal, el cual parte del academicismo, pero también adopta características de algunas vanguardias de la época. Rita Eder (1983) da un paso al etiquetar a Orozco como impresionista; a su vez, asemeja su trabajo con la pintura moderna alemana de Emil Nelde o Max Beckman (p. 154). A pesar de ello, Eder apunta que su antecedente directo sería el Greco. Si bien se asemeja a Orozco con el impresionismo, se hace mención a que no se puede clasificar a Orozco en este grupo. Ello debido a que sus representaciones son "miméticas" y no abstracciones. Posteriormente, indica la autora, Orozco añade toques personales de futurismo. Ello está representado en la gráfica de máquinas, bayonetas y objetos metálicos. El artista comienza a incluir el color gris de los uniformes y a representar a personajes con rasgos mecánicos, como es el caso del Cortés pintado en el Hospicio de Cabañas (p. 154).

Podríamos hablar de aquellas "influencias" del artista. Dicho acto superficial es refutado por Clemente Orozco, este no se ve como un símil de otra línea de producción. Se encuentra consciente de la posibilidad de crear material propio y de relevancia internacional dentro de México. Sumado a ello, se puede encontrar un sentido crítico en cuanto a lo mexicano. El artista aboga por un rescate ecléctico para la construcción de la identidad, sin planteamientos victimistas o de superioridad chauvinista. Es así como Orozco resalta y se diferencia del resto de los muralistas mexicanos. 
Revista Herencia, Vol. 34 (2), enero-junio, 2021.

El arte del Nuevo Mundo no puede enraizarse en las viejas tradiciones del Viejo Mundo, ni tampoco en las tradiciones aborígenes representadas por lo que resta de nuestros antiguos pueblos indígenas, a pesar de lo cual, todas las razas de todos los tiempos tienen un valor común humano universal, cada nuevo ciclo debe trabajar por sí mismo. Si nuevas razas han de producir un nuevo arte en un nuevo medio espiritual y físico, cualquier otro camino es síntoma de cobardía. (Orozco. en Eder, 1983, p. 155). 
Revista Herencia, Vol. 34 (2), enero-junio, 2021.

\section{Miguel Hidalgo aboliendo la esclavitud}

Figura 5: "Miguel Hidalgo aboliendo la esclavitud", de José Clemente Orozco (1937)

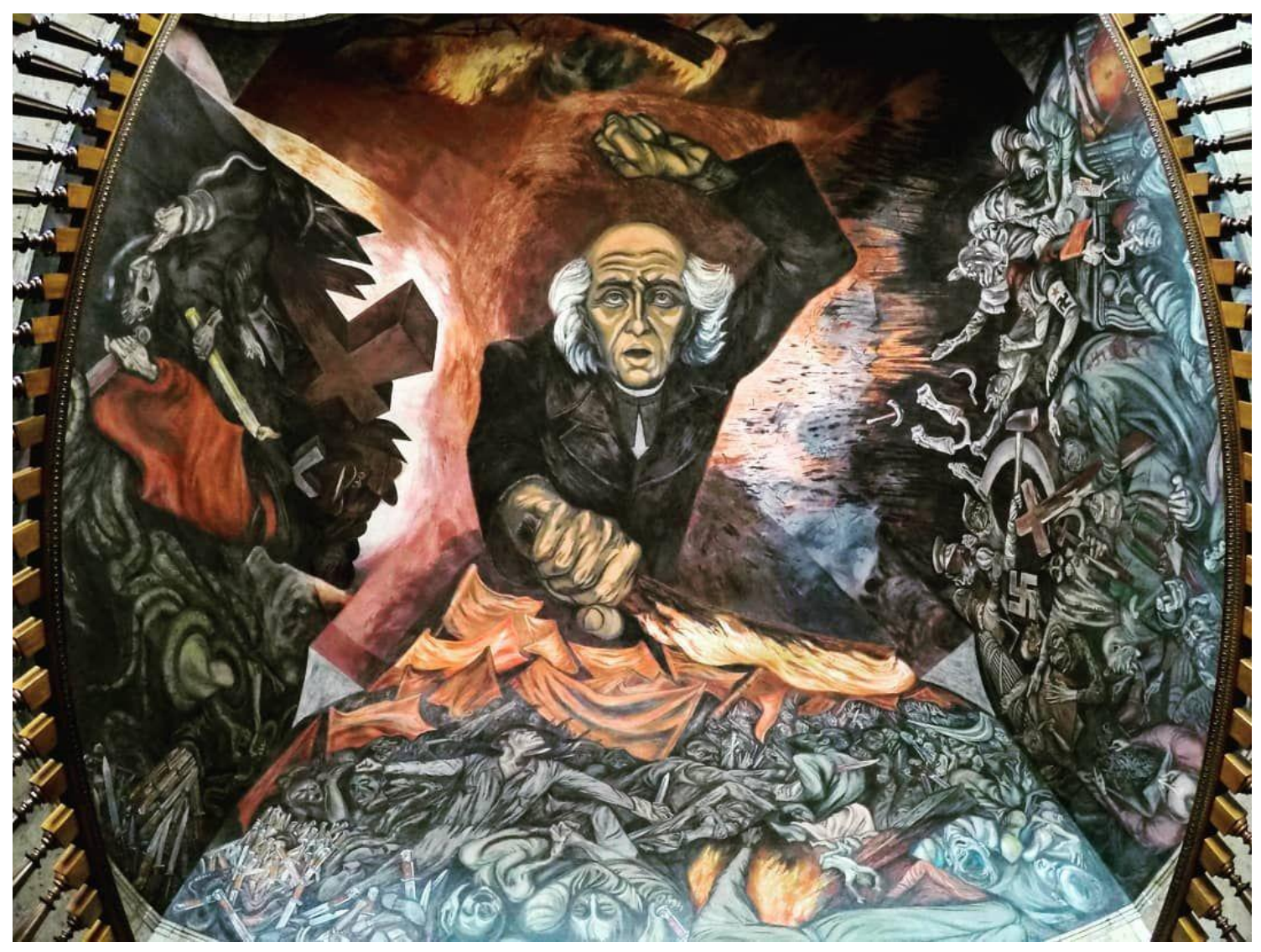

Fuente: Palacio de Gobierno de Guadalajara, México

Como menciona Rodolfo Vega (2011), el mural de Clemente Orozco (figura 5) se ubica en la escalera del Palacio de Gobierno de Guadalajara y fue pintado en 1937. Cube un área total de 345 metros cuadrados (p. 2-3). Se puede entender que la composición atiende a la estructura del espacio y la perspectiva del visitante; así como menciona Marie Pierre Ramouche (2012), al entrar al recinto se puede observar a "la masa" de los muros (representados en tonalidades grises); al avanzar hacia adentro, hace presencia Miguel Hidalgo (p. 51). Siguiendo con lo mencionado por la autora, la obra se puede dividir en tres partes. La primera comprende en el muro frontal y la cúpula. Dicho espacio contiene 
Revista Herencia, Vol. 34 (2), enero-junio, 2021.

a Miguel Hidalgo y una parte de la masa de personas en grises. El muro a la derecha es denominado como "El carnaval de las ideologías" o "Circo político". Mientras que al lado derecho se observa "Los Fantasmas de la Religión” (p. 52). También es posible separar segmentos de la obra mediante el color. En la parte superior se encuentra el cura de Dolores y en la inferior la masa. Detrás del personaje principal, se puede observar distintas tonalidades rojas. Hacia al lado izquierdo, se observa una cruz con un trazo color blando que rodea la parte superior del artefacto y lo resalta del fondo de color rojo. Este fondo posee trazos suaves, pero con una formación en remolinos. En el lado derecho, podemos encontrar tonos oscuros cerca de la masa de gente. Los trazos son rectos, con líneas verticales que apuntan hacia Hidalgo, junto con manchas y nubes oscuras. Se puede observar parte del fondo rojo, pero en su mayoría es opacado por la pintura negra. Para Ramouche (2012), dicho fondo representa "remolinos de sangre".

Es así que dentro de este espacio hace aparición Miguel Hidalgo y Costilla. Se puede observar que posee un rostro avejentado. Son predominantes las líneas de expresión en su frente y en sus labios, además de poseer ojeras y cabellos canosos a los extremos de la cabeza. La vestimenta y la morfología del personaje provienen de las facetas de religioso o intelectual. A pesar de ello, este Hidalgo pierde distintos elementos de su iconografía al encontrarse en un ambiente ajeno a su estudio. Tampoco posee alguna herramienta o estandarte de la Virgen de Guadalupe. En cambio, posee una antorcha en la mano derecha, la cual extiende hacia adelante e inclina la antorcha hacia la izquierda. Mientras que el fuego en esta llega desde inicio de la madera y recorre la antorcha hasta casi tocar la mano del religioso. La mano izquierda, se encuentra levantada en el aire y su mano en posición de puño. En cuanto al rostro, posee la boca entre abierta, casi neutral. Sus ojos los direcciona hacia arriba, mientras que las cejas no se encuentran arqueadas o expresivas.

Este gran espacio de color donde se encuentra Hidalgo, se antepone al grupo de individuos que se encuentra en la parte inferior. Aquí se puede notar un juego de colores. Los distintos personajes de "la masa" se encuentran en grises. Los objetos en cambio se encuentran en tonalidades rojas. Esta se puede encontrar en distintos objetos de carácter 
Revista Herencia, Vol. 34 (2), enero-junio, 2021.

ideológico como cruces, esvásticas, gorros frigios y demás. Es así que la tonalidad roja es predominante en toda la obra mural. Si seguimos la relación entre este color y la sangre, se puede connotar que la presencia de este color advierte el conflicto o todo aquello relacionado con ideologías. Una serie de elementos a resaltar son los cuchillos de empuñadura roja que se encuentran en el lado inferir izquierdo de este segmento; los cuales, provienen del área a la izquierda denominada "El fantasma de la religión".

Entre la masa e Hidalgo se puede observar distintas banderas rojas. Bajo estas, se halla una gran cantidad de gente. Se puede observar a un individuo con brazos extendidos y con el rostro en dirección al religioso. Por otro lado, se puede encontrar a un hombre apuñalando a otro. Se puede distinguir distintos cuerpos acumulados uno sobre otro; entre estos, restos de infantes en el lado inferior izquierdo. Al lado derecho, se puede encontrar un segmento con fuego, este parece surgir de un cadáver colocado horizontalmente en la parte inferior. El escenario muestra expresiones de sufrimiento e ira. Es un escenario bélico donde hacen presencia distintos cuchillos atravesando los cadáveres, manchados de sangre. El trabajo de color en esta área nos muestra a una masa gris, de la cual se observan los cuchillos y el fuero; ambos en tonalidades rojas.

En el lado izquierdo de encuentra "El fantasma de la religión" (figura 6). Este segmento presenta a distintos personajes a los cuales no se les puede ver el rostro; sin embargo, se puede distinguir, por la forma de sus sombreros, que son autoridades religiosas y militares. Estos se encuentran en el lado superior izquierdo del área. Dentro de este conjunto de personajes, hacen presencia dos cruces: una en tonalidad roja y de tamaño prominente; y otra más pequeña, de tonalidad gris. Entre los distintos objetos que podemos encontrar destacan una vela, un gorro militar, una bandera roja, una espada con la punta ensangrentada y un báculo con un cráneo al final. Debajo de la tela roja, podemos encontrar una mano la cual sujeta una espada. Además de ello, debajo de la prenda salen distintas serpientes, las cuales sujetan un cuerpo; mientras que, en la esquina inferior derecha, uno de estos animales expulsa cuchillos de su boca. Estos son los que conectan este mural con el del medio. Como apunta Ramouche (2018), dicho segmento representa los sectores "retrógrados dominantes": el clero y los militares (p. 53). 
Revista Herencia, Vol. 34 (2), enero-junio, 2021.

Figura 6: Segmento izquierdo del mural: "El fantasma de la religión"

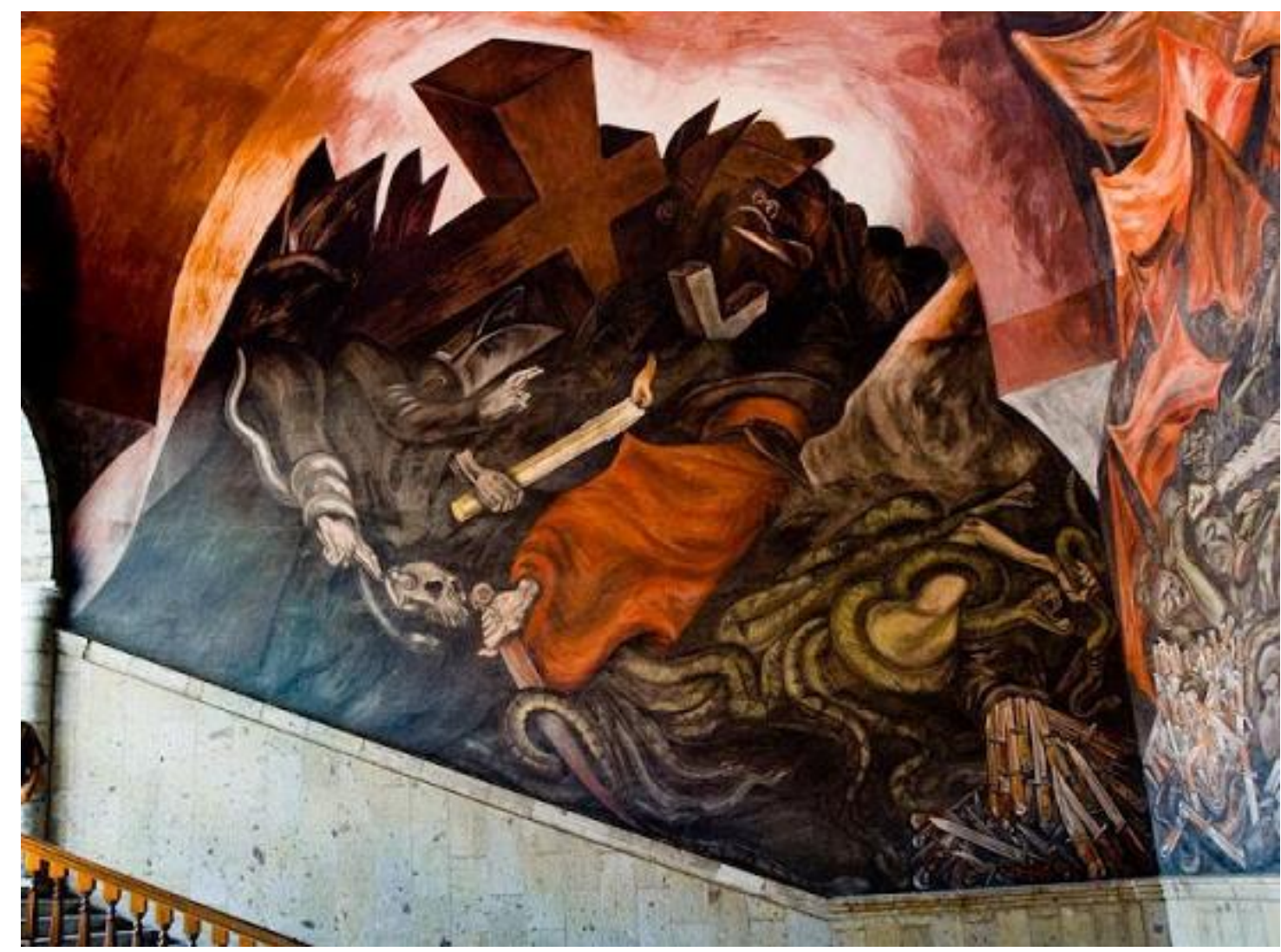

Fuente: Palacio de Gobierno de Guadalajara, México

Por su parte, "El desfile de las ideologías" (figura 7) presenta muchos más elementos y rostros a diferencia del mural a la izquierda. Los diversos personajes se encuentran dialogando entre sí, intercambiando miradas y realizando distintas expresiones con las manos. Entre estas expresiones, se puede encontrar el saludo nazi. Por encima de estos personajes grises se encuentran distintos elementos referentes a las ideologías de la época. Hace aparición la esvástica del nacional socialismo alemán, el gorro frigio de la Revolución Francesa, la cruz católica, estrellas rojas, fascios que representan la ideología fascista y la hoz y el martillo que son los componentes del símbolo del comunismo. 
Revista Herencia, Vol. 34 (2), enero-junio, 2021.

Además de estos elementos que referencian directamente las posturas de la época, también se puede observar un tambor y violines en la parte inferior del mural.

Figura 7: Segmento derecho del mural: "El carnaval de las ideologías"

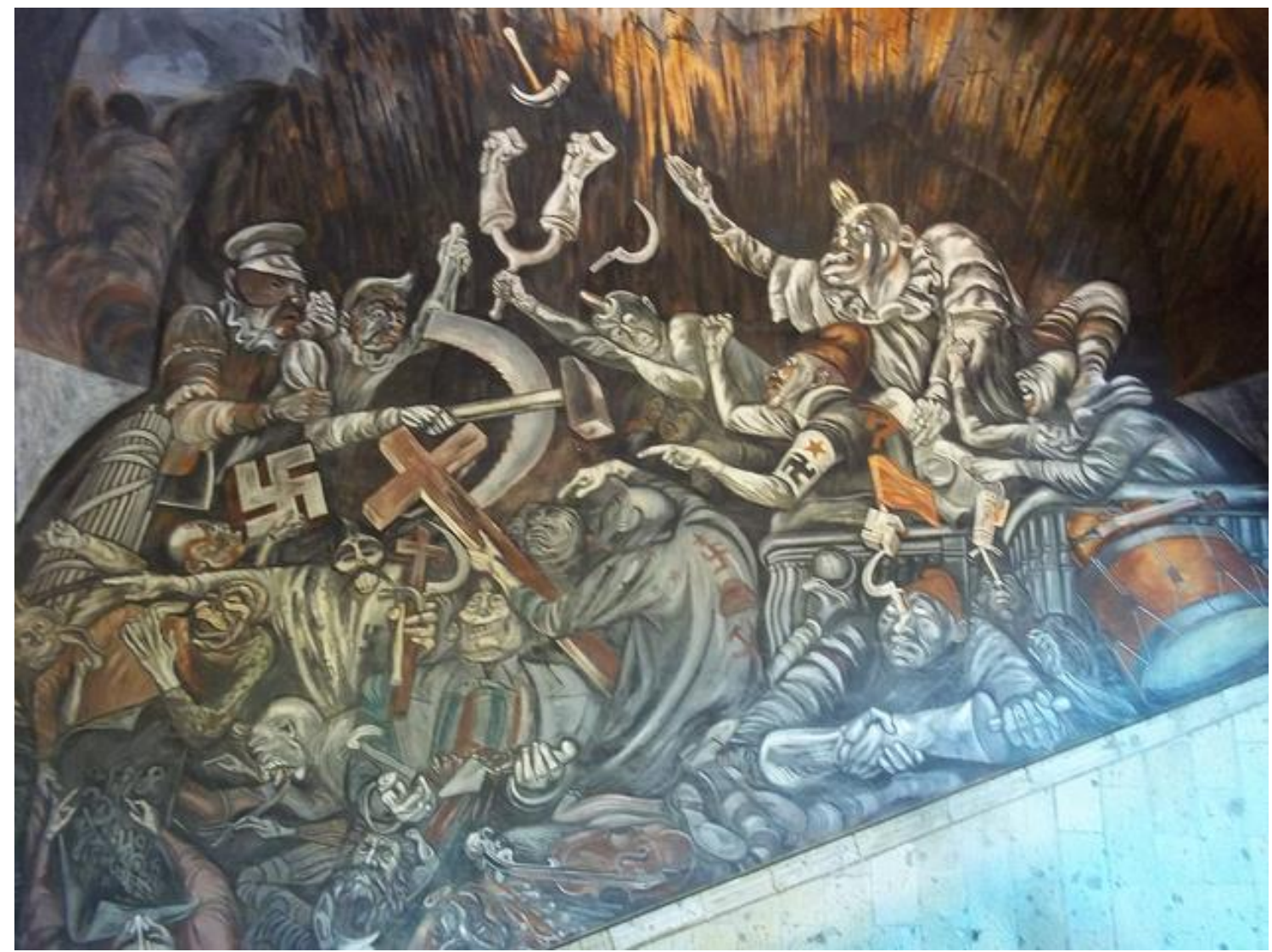

Fuente: Palacio de Gobierno de Guadalajara, México

Los personajes se pueden diferenciar en dos grupos. El primer grupo se halla en la parte derecha. En este extremo, se pueden encontrar cuatro personajes sobre una estructura que asemeja a un balcón. Entre los elementos que presentan se encuentra un gorro frigio y una banda de brazo, distintivo del nazismo. Además, se puede identificar dos personas con vestimenta similar a unos payasos: un mameluco blanco y labios rojos. El primero a la izquierda, levanta el dedo índice de su mano derecha, en expresión de reclamo. El segundo se encuentra subido sobre el anterior personaje, con su pie izquierdo sobre el hombro del anterior. Este otro individuo tiene rasgos de payaso: una vestimenta más exagerada, labios 
Revista Herencia, Vol. 34 (2), enero-junio, 2021.

y mandíbula pronunciados, calvicie y una coronilla en el lado derecho de su cráneo. Este a su vez levanta su mano derecha; mientras que la izquierda, sujeta un documento, el cual sujeta también el anterior personaje mencionado. Ambos entes miran directamente hacia un par de personajes ubicados en la parte superior izquierda. Al extremo del balcón se encuentra un adulto de bigote, mejillas y labios rojos; este usa un gorro frigio, una casaca con una hoz y martillo en la espalda y una banda de brazo con una esvástica y una estrella roja. Este tiene el puño derecho levantado y el otro brazo apunta hacia una cruz. Tras el personaje, se presenta un demonio de un solo cuerno en la cabeza y desnudo. Con la mano izquierda apunta hacia la luz de la imagen; mientras que la derecha levanta un objeto en forma de "Y". En las puntas de la forma, se observan puños y antebrazos; alrededor de estos, se encuentra una hoz y un martillo sostenidos en el aire. El demonio mencionado, observa hacia el anciano del bigote. Con respecto a estos cuatro personajes, podemos identificar el papel de algunos. El hombre con los diversos símbolos en su vestimenta, es un político; quien desde su balcón es acompañado por asesores o algún aparato estatal. Los personajes vestidos de payados sujetan un documento que podría ser interpretado como las leyes o alguna carta magna. Un detalle que se pierde en el fondo son los rostros al lado izquierdo del político. Estos tienen una forma redondeada y presentan bigote similar al del personaje en primer plano. El balcón donde se encuentran estos cuatro personajes se sostiene sobre las espaldas de dos personajes en el lado inferior izquierdo. Uno de estos tiene un gorro frigio y en la punta de su nariz se balancean objetos con formas de los símbolos ideológicos. Estos son una bandera roja, una esvástica y una hoz. Mientras que el personaje a su derecha también realiza la misma acción, sólo que este equilibra un fascio y un martillo. Albos personajes observan hacia arriba; hacia "los políticos". El primer personaje, sujeta con sus manos un objeto con la forma de dos manos estrechándose. Similar al artefacto del demonio en la parte superior, este objeto sólo presenta manos y antebrazos; seguidos por un asa u objeto por donde se sujeta dichos artefactos. Estos objetos mencionados son relevantes debido a su posición y portadores. El primer objeto presenta dos puños elevados, este es sujetado por un demonio el cual parece instruir a un político. Puede ser considerado como un símbolo de la confrontación. 
Revista Herencia, Vol. 34 (2), enero-junio, 2021.

Esta última apreciación puede corroborarse con la forma del segundo objeto. No son dos brazos separados; al contrario, estos se encuentran unidos por un apretón de manos. Irónicamente, este objeto representante de la fraternidad o el diálogo se encuentra en manos de un sujeto claramente caricaturizado, incluso humillado dentro de la escena.

En el medio del espacio podemos observar una cruz sujetada por un conjunto de tres hombres de túnicas blancas. Sólo se observa la espalda de un personaje, donde se encuentran más símbolos ideológicos. Se puede observar los brazos de "religioso" en primer término. Con la izquierda, sujeta la cruz; con la derecha, apunta hacia esta. De esta manera, podemos identificar que el político, el demonio y el religioso apuntan hacia este elemento. Bajo la cruz, se puede identificar un hombre de traje, pero con distintas corbatas. Esas son dos rojas y dos azules. El sujeto mencionado observa hacia arriba con las palmas en posición de rezo. Sobre sus manos, se puede encontrar un martillo, una espátula de construcción y un fascio. Bajo este conjunto comprendido por los religiosos y "el empresario", se pueden encontrar distintas piernas humanas en el lado izquierdo; mientras que debajo del hombre de traje se encuentra un violín y dos cabezas cercenadas. Una presenta una barba pronunciada y cabello largo; mientras que otra se observa más rojiza y redonda, con bigote y una sonrisa pícara.

Al lado superior izquierdo de este segmento, se puede encontrar dos personajes en la parte superior. Uno es un militar con un antifaz; su vestimenta asemeja mucho a su arquetipo, a excepción del collarín que usa (y a su vez, es similar al de los payasos a la derecha). A su lado, se encuentra un personaje con vestimenta similar a la de un payaso; sin embargo, este presenta bigote y cabello. El militar sujeta su brazo derecho y muestra un puño sobre su hombro. En cambio, este segundo personaje sostiene con la mano derecha un martillo; con la izquierda, una hoz. Sumado a ello, se encuentra la mirada de desprecio del personaje; la cual se encuentra con las miradas de los religiosos con túnicas blancas. Bajo el militar y su acompañante, se observa una esvástica y un fascio; a diferencia de los personajes del lado izquierdo inferior, este segmento presenta personajes fantásticos. El primero es un esqueleto que sujeta con una mano el objeto en forma de esvástica; el resto de su cuerpo no se observa. A su lado, un esqueleto con cabello y un 
Revista Herencia, Vol. 34 (2), enero-junio, 2021.

bigote pronunciado; este a su vez usa un poncho blanco con esvásticas dibujadas en la tela. Sus manos no parecen esqueléticas. Con la derecha, levanta el pulgar en dirección a la izquierda del mural; mientras que, con la izquierda, sujete una cruz, un martillo y una hoz. Por debajo de su brazo se encuentra el tercer esqueleto, este posee un rostro más humanizado y de expresión pícara. Usa un atuendo que cubre sus brazos hasta las muñecas, donde continúa una mano humana. Este personaje sujeta el cuerpo de un personaje en traje rojo; del cual no podemos ver su cabeza o rostro. A la izquierda de ellos se encuentra una cabeza, la cual parece ser de piedra. Los rasgos de este objeto asemejan al fenotipo de un griego, quizá en referencia a algún filósofo. Ello tiene sentido al observar a un personaje vestido de rojo en la parte inferior derecha del segmento. Dicho personaje escribe en un ahoja la cual posee distintos números ordenados de manera caótica. No se puede afirmar si el personaje sujetado por el esqueleto de arriba es el mismo personaje que escribe. Debido a la posición de ambos sujetos, se puede generar un sentido de relación. Quizá un causa y efecto de encontrarse vestido de "rojo ideología", asumiendo que el rol de aquel sujeto es el de un "ideólogo". El último personaje a mencionar es un demonio que observa las escrituras del ideólogo. Este posee un único cuerno, una oreja en punta y la lengua hacia afuera; su expresión denota deseo o atracción hacia el elemento que observa: la obra del ideólogo. Se puede observar más de unas tres manos en dirección a las escrituras; por su posición, todas podrían venir de aquel demonio.

Como se ha mencionado, existe una clara división entre el espacio con color donde se encuentra Miguel Hidalgo y el gris de la masa. Dentro de este conjunto, se puede diferenciar a distintos personajes; pero, sobre todo, el color rojo presente en diversos objetos y personajes. Si bien se apunta a ese color como un símil de la sangre, se puede pensar en ello como una metáfora de la ideología. Es así como encontramos a un Miguel Hidalgo envuelto en ideología, mientras que abajo la ideología se presenta en los diversos objetos e incluso en los labios de algunos personajes. Ello es más explícito en "El carnaval de las ideologías", donde cada elemento que representa alguna postura es presentado con una tonalidad rojiza. Al pensar en el rojo como "lo ideológico", se puede entender la intensidad de este color en el fondo tras Hidalgo. Se observa un rojo más oscuro alrededor 
Revista Herencia, Vol. 34 (2), enero-junio, 2021.

de su calva. Por el lado izquierdo, este rojo es diluido por el blanco que emana una cruz. Por el lado derecho, este presenta distintas manchas negras seguidas por los rayos oscuros provenientes del tumulto de personas. Ante esta observación, Gonzáles Mello en Ramouche (2018) apunta a que el color gris de las personas imposibilita agrupar a estos en uno de los bandos descritos (53). Por lo anterior, en el mural central la masa no presenta estos objetos en sus vestimentas, pero sí podemos encontrar los diversos cuchillos con pintura roja, un personaje apuñalado y un cadáver junto a una bandera. En el lado izquierdo, la ideología se encuentra presente en la cruz, en la cinta del gorro militar, la tela roja y el cuchillo el cual es rodeado por la serpiente. Es finalmente la serpiente, quien regurgita los cuchillos de rojo que abarcan hasta la esquina inferir izquierda del muro central. En el segmento derecho, los elementos no sólo se llevan en la mano, sino que también forman parte de la vestimenta y el maquillaje de los personajes. Si bien las personas son grises, es el color rojo el que va a marcar la presencia de la ideología. Se representa así un segmento central con individuos que poseen banderas rojas; estos, a su vez, reciben cuchillos pintados de rojo. Al lado inferior derecho se encuentra un asesinato por ideología y un hombre muerto al lado de su bandera roja. En los extremos de esta masa defensora de su ideología, se ve la influencia de otras fuerzas; en principio la religión y el militarismo, quienes se ven como personajes anónimos. En el lado derecho, se encuentra un conflicto con una diversidad de elementos ideológicos. Los murales a los extremos poseen conexiones con el segmento central. Del lado izquierdo provienen los distintos cuchillos; mientras que el derecho, se encuentra una calavera apuntando hacia la masa. La división del encuadre puede explicarse con la intervención de Justino Fernández en Ramouche (2018), el cual apunta que en mural se presenta la "separación entre la realidad y el idealismo" (p. 54). Ello representado en el área de fondo rojo y la masa.

La expresión de Hidalgo no es enfática ni eufórica. Se puede decir que es una expresión neutra o próxima al asombro, debido a la posición de su boca y cejas. Como se ha detallado, a diferencia de las representaciones de Siqueiros y Rivera, el Hidalgo de Orozco no es presentado de manera heroica o noble. Si bien el personaje se encuentra en una 
Revista Herencia, Vol. 34 (2), enero-junio, 2021.

posición privilegiada, este parece dirigir su atención en dirección contraria a las masas. Eder (1983) menciona que este Hidalgo posee relación con el mito griego de Prometeo. Dicho relato estaría relacionado con los estudios dentro del Círculo Délfico que frecuentaba Orozco. En este se relacionaba al titán con la libertad, pues este había sido quien entregó el fuego y las artes a la humanidad. Incluso se menciona un sentimiento mesiánico relacionado con la labor de Prometeo; el cual tiene la labor de ayudar a ascender a la humanidad (157-8).

La interpretación del mural puede plantearse desde una perspectiva nacionalista, que infiera el valor heroico de Miguel Hidalgo. Sin embargo, la diferencia entre el espacio del caudillo y de las masas es considerable. A pesar de la división generada por el color, el rojo que representa la ideología recorre los tres murales. Este, a su vez, se representa en estos objetos relacionados cada uno con los distintos planteamientos políticos. Es correcto pensar que son presentados dos planos: el mundo real y el mundo de las ideologías. En el primero, no existe diferencia en los individuos; en cambio, el elemento político está presente en sus objetos o vestimentas, generando así a los personajes ideologizados. Por su lado, Hidalgo se encuentra envuelto en esta metáfora y el color que la gráfica puede incluso marcar un sentido de fantasía o abstracción. Por lo tanto, el mural de Orozco nos presenta un Hidalgo que puede ser tomado como un personaje heroico; sin embargo, este pertenece a las ideas de un pueblo graficado en grises. Estos últimos se etiquetan y discuten con los diversos "objetos ideológicos". Costilla no observa a las masas, sino que este mira arriba, lo cual puede indicar la realización de una plegaria o la demostración de arrepentimiento ante Dios. Como se ha mencionado, el rostro de Hidalgo no presenta una expresión marcada; en aquella ambigüedad, es posible plantear algunas ideas distintas a las expresadas sobre el mural. Quizá podría tratarse de un Hidalgo arrepentido al observar el conflicto de las masas. Ello sustentado en el sentido crítico de Orozco, el cual no necesariamente poseía el ímpetu para resaltar o enardecer aquellas imágenes impulsadas por el gobierno y los otros muralistas. 
Revista Herencia, Vol. 34 (2), enero-junio, 2021.

\section{Conclusiones}

En primer lugar, se debe tener en cuenta la diferencia ideológica entre Miguel Hidalgo y el marxismo. El religioso respondía sobre el populismo jesuita. Dicha ideología es propia de una época con monarcas. En cambio, el marxismo surge durante la época industrial. Se puede decir que ambos poseen un accionar que impulsa al rompimiento del contrato social en caso de un "mal gobierno". En el caso del marxismo, este se ve reflejado en la representación del "burgués" como el símbolo del atraso, diferente a los denominados "gachupines" de Nueva España. Es así como Hidalgo no es representado bajo planteamientos marxistas, sino que es un personaje producto de su historia, exaltado por su actitud insurgente o "rebelde"; aunque, por otro lado, no logra ser asimilado totalmente por el ambiente romántico o el trato que reciben los líderes de los bandos revolucionarios.

Podemos entender que Siqueiros y Rivera fueron artistas que imaginaron a Hidalgo como un ser virtuoso o líder rebelde, debido a sus ideas y posturas políticas durante la Revolución Mexicana y la Guerra Fría. Con respecto a Orozco, este participa de la izquierda, pero no logra comprometerse con esta. El artista se mantiene con una posición crítica ante los distintos planteamientos del "manifiesto" del sindicado de Siqueiros. Este distanciamiento y crítica es claramente observable en "el carnaval de las ideologías" donde realiza una evidente representación del conflicto ideológico de la época, y dota a estos personajes de aspecto caricaturesco; de igual manera con la vestimenta de arquetipos como el payaso o el militar. La distancia ideológica posibilita la descripción cruda e irónica ante los distintos bandos.

La división del mural es fundamental. Como se ha mencionado, existe un espacio cromático donde se encuentra Hidalgo; por debajo de este, se observa una masa de distintos personajes en tonalidad gris. El color rojo en distintas tonalidades va a ser el elemento que une estos dos espacios. El color representa "lo ideológico". El cura de

Dolores se encuentra en este espacio, en el mundo de las ideas. Por otro lado, se encuentran las personas de gris; este color imposibilita diferenciarlos por el color de la piel 
Revista Herencia, Vol. 34 (2), enero-junio, 2021.

o sus prendas; por lo cual, son convertidos en una masa. Sin embargo, el color rojo de la ideología se representa en los distintos "objetos ideológicos". Así, la masa del centro no se ve diferenciada o politizada. Esta expresa sus ideas con las banderas que sujeta. Por otro lado, es válido mencionar el conflicto donde hace presente el rojo; ello es visible en el hombre apuñalado, donde se hace presenta la metáfora. En el segmento derecho del mural, se entiende que los diversos personajes se diferencian debido a la presencia de sus ideologías, representando estas posturas en sus vestimentas, objetos y maquillaje.

El mito de Prometeo es un símil adecuado para la representación de Miguel Hidalgo. El paralelismo lo encontramos al describir la labor de ambos personajes en el momento de brindar una herramienta a las masas. Prometeo, el fuego; Hidalgo, la insurgencia. Sin embargo, la expresión del caudillo no es de regocijo o de ímpetu. Puede pensarse que la expresión denota lástima o lamento. Es así como se puede entender al Hidalgo de Orozco como un personaje arrepentido del conflicto cometido por las masas. Incluso el juego del color sirve como contraste entre el color del mundo de las ideas, en contraposición con el gris de la realidad, pintado con aquellos objetos o significantes de las ideologías.

Clemente Orozco, a diferencia de Siqueiros y Rivera, presenta a un Hidalgo idealizado. Sin embargo, su planteamiento se aleja de romanticismo entorno al padre de la patria; en cambio, lo presenta como un Prometeo. Es así un Hidalgo consiente de las consecuencias de la lucha insurgente; este a su vez, no se encuentra dentro del mundo real, es ahora parte del mundo de las ideas. Es aquel espectro ideológico que se presenta con el rojo; presente en objetos de carácter ideológico y en los labios de los personajes. Al igual que Prometeo, Hidalgo lleva aquel fuego a la humanidad; aquello que cala en las ideas que diferencian a los individuos. Ello es más presente en el segmento derecho del mural, donde hace presencia personajes más individualizados. Es en esta área donde se presenta una gran cantidad de elementos simbólicos; los cuales, a su vez, presentan un escenario fantástico y cómico sobre el ejercicio de debate entre estas ideologías de la época. Aunque por el orden y la presencia de los símbolos de cada bando, no se puede señalar la preferencia del artista por algún bando. El mural es una crítica estructurada y detallada sobre la sociedad mexicana y las ideologías de la época en que vivió Orozco. 
Revista Herencia, Vol. 34 (2), enero-junio, 2021.

\section{AGRADECIMIENTOS}

Agradezco al Hobbit de Migala y a los Bully Magnets. Ambos creadores de contenido fueron inspiración para investigar a Orozco y a la historia de México.

\section{BIBLIOGRAFÍA}

Brenes, G. (2010). Miguel Hidalgo a la luz del arte: iconografía del héroe nacional padre de la patria mexicana siglo xix xx. Kañina, Revista de Artes y Letras, Universidad de Costa Rica. XXXIV(2), 53 -71.

Baz, G. (1887). Miguel Hidalgo y Costilla Ensayo Histórico biográfico. México. Biblioteca Nacional de México.

Castillo, R. (2010). José Clemente Orozco, pintura y verdad. Ciudad de México: Litoprocess.

Exposición de pintura mexicana Museo Nacional de Bellas Artes. (1973). Embajada de México, Santiago de Chile. 
Revista Herencia, Vol. 34 (2), enero-junio, 2021.

Eder, R. (1983). De héroes a máquinas: reflexiones para la reinterpretación del estilo y las ideas en la obra de José Clemente Orozco. Universidad Nacional Autónoma de México.

Fernández, M. (2013). Los Sentimientos de la Nación de José María Morelos. Antología documental. Instituto Nacional de Estudios Históricos de las Revoluciones de México.

Gonzáles, O. (2014). La primera construcción mítica en torno a Miguel Hidalgo. Revista Col. San Luis [online], 4(8), $160-190$.

Herrejón, C. (1987). Hidalgo: la justificación de la insurgencia. Relaciones IV(13), 31 53.

Herrera, J. (2010). El Rostro de Miguel Hidalgo. (Web). http://puertanorteacaponetajimsh.blogspot.com/2010/09/el-rostro-de-hidalgo.html

Jaimes. H. (2012). Filosofía del muralismo mexicano: Orozco, Rivera y Siqueiros. Madrid: Editorial Plaza y Valdez.

Marín, J. (2009) Miguel Hidalgo y la independencia. Universitarios Potosinos, 5(VIII), 26 $-31$. 
Revista Herencia, Vol. 34 (2), enero-junio, 2021.

Ortiz, A. (2007). Cultura y política en el drama mexicano post revolucionario (1920 1940). Murcia: América sin nombre.

Orozco, C. (1945). Autobiografía. Editorial Planeta. España.

Rodríguez, A. (2015) Orozco: ¿Pintor sin ideología? Fuentes Humanísticas, 27(53), II semestre 2016, $165-174$.

Ramouche, M. (2012). Miguel Hidalgo: un héroe dual en Sublevación de José Clemente Orozco. América, 42, 49-57. 
Revista Herencia, Vol. 34 (2), enero-junio, 2021. 